\title{
Экспертиза
}

КИСлИЦыН Сергей Алексеевич - доктор исторических наук, профессор факультета политологии Южно-Российского института управления РАНХиГС при Президенте РФ (344002, Россия, 2. Ростов-на-Дону, ул. Пушкинская, 70; kislizins@yandex.ru)

\section{ПРЕДПОСЫЛКИ ИНТЕГРАЦИИ ДЕ-ФАКТО СУВЕРЕННЫХ НАРОДНЫХ РЕСПУБЛИК ДОНБАССА В ПОСТСОВЕТСКИЕ ОБЪЕДИНЕНИЯ С УЧАСТИЕМ РОССИЙСКОЙ ФЕДЕРАЦИИ}

\begin{abstract}
Аннотация. В статье раскрываются цивилизационные и исторические военно-политические основания функционирования Луганской и Донецкой народных республик. По мнению автора, ДонецкоКриворожская советская республика в 1918 г. создала необходимый правовой прецедент для формирования государственного суверенитета современных донбасских республик. Решение В.И. Ленина о ликвидации ДКСР имело значение для советизации Украины, но также негативные последствия для постсоветской системы отношений. Автор обращает внимание на опыт эвакуации под нажимом войск германских интервентов шахтерской армии под командованием К.Е. Ворошилова, что также стало одним из факторов обнуления перспектив Донецко-Криворожской республики. Перспективы республик Донбасса связаны с объединением двух народных республик в одно государство согласно прецеденту исторической Донецко-Криворожской республики и последующим вхождением нового образования в существующие интеграционные объединения на постсоветском этногеополитическом пространстве. Ключевые слова: Донецко-Криворожская республика 1918 г., Донецкая и Луганская народные республики, непризнанные государства, гражданская война на Востоке Украины, интеграция постсоветского пространства
\end{abstract}

$\mathrm{H}$ епризнанные Донецкая и Луганская народные республики стали реальными политическими субъектами международных отношений, прежде всего между Россией и Украиной. Почти 5 лет существования де-факто государственного суверенитета, боеспособной армии и собственной экономики фактически сняли вопрос об их временности и нелегитимности. Но для обоснования возможности суверенности народных республик Донбасса нужно в большей мере использовать объективные исторические социально-экономические факторы, предопределившие именно такой вариант развития событий.

Первый из них - это наличие цивилизационно целостного русскоязычного региона угольного бассейна. В Донецкий каменноугольный бассейн, где находятся крупные месторождения каменного угля, входят современные украинские Донецкая обл. (исключая Приазовье), южная часть Луганской обл. и часть российской Ростовской обл. Следует подчеркнуть, что Донецкая и Луганская территории и бывший Ростовский уезд исторически являлись так называемой Новороссией. В 1783 г. было образовано Екатеринославское наместничество, ставшее в 1803 г. губернией. В 1847 г. губернатор Новороссийской губернии М.С. Воронцов направил историка-статистика А.А. Скальковского с миссией обследования г. Ростова-на-Дону и близлежащих районов на предмет их развития. В 1887 г. Ростовский уезд и Таганрогское градоначальство были отделены от Екатеринославской губернии и вошли в состав казачьей области войска Донского. Длительное совместное развитие интересов и хозяйства областей Украины и России привело к неформальному объединению их в общий религиозно-культурный и социально-экономический регион - Большой Донбасс. 
Причем этот по своему характеру исключительно шахтерский регион стал опорной базой большевистской революции на Украине и всем юге бывшей Российской империи. И в годы Гражданской войны Донбасс сыграл решающую роль в разгроме украинской и белоказачьей контрреволюции.

Особую роль в формировании особой донбасской идентичности сыграли конкретно-исторические обстоятельства, которые обусловили вскоре после Великой российской революции 1917 г. образование в январе 1918 г. ДонецкоКриворожской советской республики [Корнилов 2017]. Этот исторический факт имеет принципиальное значение, поскольку он сформировал правовой прецедент развития самостоятельной русскоязычной государственности, развивавшейся параллельно с украинской государственностью - Украинской Народной Республикой (УНР). После декабрьского 1917 г. съезда Советов ДонецкоКриворожского бассейна был избран областной исполком, который попытался организовать «областную» республику в противовес УНР, которая квалифицировалась им как буржуазное государство. Артем (Сергеев), С. Васильченко настаивали на том, что республики Федерации Российской Социалистической Республики должны строиться не по национальному признаку, а согласно особенностям национально-хозяйственного быта. Они исходили из того факта, что население этого региона было в своем подавляющем большинстве русским и не имело к Украине этнического отношения. Украинские национальные движения развертывались в основном на территории правобережной Украины и воспринимались рабочими Донбасса как чуждые по всем параметрам - и национальным, и социальным. Спустя почти 100 лет, когда на Украине развернулась националистическая травля русских рабочих Донбасса, очевидно, что данная аргументация была вполне рациональной. Но в Москве образование независимой от Украины Донецко-Криворожской советской Республики сочли ошибкой, порожденной непониманием перспектив национально-государственного строительства и советизации Украины. Совнарком РСФСР не признал ее ни самостоятельной республикой, ни частью Российской Федерации. В телеграммах представителям СНК в Украине Г. Орджоникидзе и В. АнтоновуОвсеенко В.И. Ленин требовал соблюдения суверенитета Советской Украины, невмешательства в деятельность ЦИК Советов Украины, «тактичности» в национальном вопросе, заботы об укреплении сотрудничества Украинской и Российской советских республик. Лидеры большевиков считали, что без пролетариата Донбасса будет очень трудно развернуть мелкобуржуазные западную и центральную Украину на путь социалистического строительства. Решение В.И. Ленина о ликвидации ДКСР имело позитивное значение для советизации Украины, но на современном этапе обнаружились его негативные последствия для постсоветской системы.

31 января (13 февраля) в Бресте делегация Украинской Народной Республики обратилась с меморандумом к Германии и Австро-Венгрии с просьбой о помощи для борьбы с советскими войсками. Воевать с Германией на равных было тогда невозможно, и руководство приняло решение об эвакуации органов власти и армии.

В мае-июне 1918 г. красногвардейские шахтерские отряды ДКСР, развернутые в составе 5-й армии под командованием Ф.А. Сергеева, К.Е. Ворошилова, Б.И. Магидова, А.Я. Пархоменко, под напором интервенционистских австрогерманских войск совершили героический переход от Харькова до Царицына. 15 бронепоездов, 80 эшелонов и 40 тыс. бойцов с семьями и беженцами прошли через белогвардейский Дон с боями 500 км. В 1930-х гг. этот поход, объявленный легендарным ворошиловским, непомерно героизировался, а в Новое время его фактически забыли, что также является некорректным. Между тем 5-я армия 
K.Е. Ворошилова сыграла значительную роль в обороне на Царицынском фронте. Однако Донецко-Криворожская республика перестала существовать и юридически, и фактически. Очень важно, чтобы героико-трагичный опыт эвакуации армии донецких шахтеров не повторился в новых условиях.

5 февраля 1919 г. установившееся украинское советское правительство приняло декрет об образовании Донецкой губернии, которая стала 2 июня 1932 г. Донецкой областью УССР. В годы Великой Отечественной войны на территории переименованных Сталинской и Ворошиловградской обл. практически отсутствовала бандеровщина как этнополитический феномен. Но после обретения независимости Украина стала пристанищем старых бандеровцев и новых неофашистов. Поэтому с начала XXI в. в юго-восточных регионах Украины стали нарастать антибандеровские (антинационалистические) настроения, которые постепенно привели к реальным акциям протеста русскоязычного населения против действий правых неофашистских сил. Партия регионов во главе с В. Януковичем не предпринимала решительных действий по пресечению национализма и тем самым фактически потворствовала их деятельности.

Современное экономическое единство Донбасса базируется на этнополитической общности восточных украинцев и русских. По данным переписи населения 1989 г., в Донецкой обл. доля украинцев формально составляла 50,7\%, русских - 43,6\%. В 2001 г. в Донецкой обл. доля украинцев составляла 56,9\%, а русских $-38,2 \%$, в Луганской $-58 \%$ и $40 \% 1$. Но самое главное заключается в том, что русский язык считают родным 74,9\% населения, в Луганской обл. - 68,8\%, а используют его на практике буквально все. Если учесть особую близость языков, генотипов и ментальных архетипов населения, то можно уверенно говорить об фактически этнически однородном населении. Эти показатели идентичности соответствуют практически всему юго-востоку Украины, за некоторым исключением (бывшая украинская, а теперь российская республика Крым, где русских $65 \%$, а украинцев - $15 \%$, а русский язык - родной для 84\%). Но все эти цифры не учитывают абсолютно доминирующий русский характер культуры этого региона, что делает его имманентной частью русского мира - ядра российской евразийской цивилизации. По большому счету, и центральная часть Украины всегда была ее компонентом, но в силу форсированно стимулируемой режимом украинизации культуры в центральном регионе произошел цивилизационный и религиозный раскол со всеми характерными для него негативными последствиями. Этот факт неожиданно признали в своих последних выступлениях экс-президенты Украины Л. Кравчук и В. Ющенко.

Когда националисты после государственного переворота 2014 г. захватили руководство Украиной, гражданское общество Донбасса отказалось признавать новую киевскую власть и выступило за федерализацию Украины, в т.ч. за автономию Донбасса. Поскольку пришедшее к власти правительство представляло интересы в основном Западной Украины, носители русского языка и культуры из восточных регионов обоснованно выступили против доминирования во власти неофашистских партий. Неонацисты запретили коммунистическое интернационалистское движение, и сопротивление пошло по другому пути. Началась Русская весна - активизация русскоязычного гражданского общества и его героическая борьба с бандерофашизмом. В Крыму этот процесс завершился референдумом и победой народа [Кислицын 2016].

Образовавшиеся Донецкая и Луганская народные республики (ДНР и ЛНР) находятся в сложных условиях, т.к. контролируемая ими территория значительно уступает территории прежних Донецкой и Луганской обл., что нега-

\footnotetext{
${ }^{1}$ https://www.turkaramamotoru.com/ru/Население-Донецкой-области-168434.html
} 
тивно влияет на экономический потенциал. Непрекращающиеся военные действия и отсутствие перспективы их быстрого пресечения создали военнополитическую напряженность, делающую невозможным длительное сохранение статус-кво. Поражение на президентских выборах лидера Партии войны П. Порошенко создало новую ситуацию, которая могла бы позволить начать примирение сторон и прекращение (по выражению И. Коломойского) «войны украинцев против украинцев». Однако вновь избранный президент «нового типа», бывший комик В. Зеленский выступает с противоречивыми заявлениями - с требованиями заключения мира и продолжения войны. Можно предположить, что до тех пор, пока на Украине у власти находятся признающие бандеровскую идеологию лидеры, полноценное сотрудничество ДНР и ЛНР с новым правящим режимом чрезвычайно затруднено. Более того, функционирование на Украине значительных вооруженных неонацистских формирований непонятного подчинения делает иллюзией все проекты о возможной автономии Донбасса. Перспективы республик Донбасса связаны, на наш взгляд, с объединением народных республик в одно государство согласно прецеденту исторической Донецко-Криворожской республики и последующим вхождением нового образования в существующие интеграционные объединения на постсоветском этногеополитическом пространстве, такие как Содружество непризнанных республик, СНГ, Евразийский союз.

\section{Список литературы}

Кислицын С.А. 2016. Политическое значение деятельности гражданского общества Севастополя и Крыма в период борьбы за интеграцию Крымской Автономной республики в Российскую Федерацию. - Власть. Т. 24. № 8. C. $48-54$.

Корнилов В. 2017. Донецко-Криворожсккая республика. Расстрелянная мечта. СПб: Питер. 575 с.

\section{PREREQUISITES FOR THE INTEGRATION DE FACTO OF THE SOVEREIGN PEOPLE'S REPUBLICS OF DONBASS INTO POST-SOVIET ASSOCIATIONS WITH THE PARTICIPATION OF THE RUSSIAN FEDERATION}

\footnotetext{
Abstract. The article reveals civilizational and historical military-political bases of functioning of Lugansk and Donetsk People's Republics. According to the author, the Donetsk-Krivoy Rog Soviet Republic in 1918 created the necessary legal precedent for the formation of state sovereignty of the modern Donbass republics. The decision of V.I. Lenin on the elimination of the DCSR was important for the Sovietization of Ukraine, but also had negative consequences for the postSoviet system of relations. The author draws attention to the experience of evacuation under the pressure of the German troops of the mining army under the command of K.E. Voroshilov that also became one of the factors of zeroing the prospects of the Donetsk-Kryvoy Rog Republic. The prospects of the republics of Donbass are connected with the unification of two people's republics into one state according to the precedent of the historical Donetsk-Krivoy Rog Republic, and its subsequent entry into the existing integration associations in the post-Soviet ethno-political space.

Keywords: Donetsk-Kryvoy Rog Republic of 1918, Donetsk and Lugansk people's republics, unrecognized states, civil war in the East of Ukraine, integration of post-Soviet space
} 